\title{
Comparison of Three Methods for Monitoring Populations of Different Genotypes of 2,4-Diacetylphloroglucinol-Producing Pseudomonas fluorescens in the Rhizosphere
}

\author{
Blanca B. Landa, Henricus A. E. de Werd, Brian B. McSpadden Gardener, and David M. Weller
}

\begin{abstract}
U.S. Department of Agriculture, Agricultural Research Service, Root Disease and Biological Control Research Unit, Washington State University, Pullman 99164.

Current address of H. A. E. de Werd: Division Glasshouse Horticulture, Linnaeuslaan 2a. 1431 JV Aalsmer, The Netherlands.

Current address of B. B. McSpadden Gardener: Department of Plant Pathology, The Ohio State University, OARDC, Wooster 44691. Accepted for publication 11 October 2001.
\end{abstract}

\section{ABSTRACT}

Landa, B. B., de Werd, H. A. E., McSpadden Gardener, B. B., and Weller, D. M. 2002. Comparison of three methods for monitoring populations of different genotypes of 2,4-diacetylphloroglucinol-producing Pseudomonas fluorescens in the rhizosphere. Phytopathology 92:129-137.

Pseudomonas fluorescens strains producing the antibiotic 2,4-diacetylphloroglucinol (DAPG) have biocontrol activity against a broad spectrum of root and seedling diseases. In this study, we determined the effect of genotype on the ability to isolate and quantify introduced 2,4-DAPG producers from the rhizosphere of wheat using three different methods: traditional dilution plating on selective media, colony hybridization followed by polymerase chain reaction (PCR), and phlD-specific PCRbased dilution endpoint assay. Regression analysis of the population densities of 10 2,4-DAPG-producing $P$. fluorescens, representing five genotypes, determined by the three different methods demonstrated that the relationship was linear $(P<0.001)$ and the techniques were very similar (i.e., slopes equal to 1.0). The $p h l D$-specific PCR-based assay had a slightly lower limit of detection than the other two methods $(\log 3.3$ versus $\log 4.0 \mathrm{CFU} / \mathrm{g}$ of fresh root weight). With the colony hybridization procedure, we observed that the phlD probe, derived from strain $P$. fluorescens Q8r1-96, hybridized more strongly to colonies of BOX-PCR genotypes D (strains W2-6, L5.1-96, Q8r1-96, and Q8r2-96) and K (strain F113) compared with strains of genotypes A (Pf-5 and CHA0), B (Q2-87), and L (1M1-96 and W4-4). Colony hybridization alone overestimated the actual densities of some strains, thus requiring an additional PCR step to obtain accurate estimates. In contrast, population densities estimated for three of the bacterial treatments (strains CHA0, W2-6, and Q822-96) with the PCR-based assay were significantly $(P<0.041)$ smaller by 7.6 to $9.2 \%$ and 6.4 to $9.4 \%$ than population densities detected by the dilution plating and colony hybridization techniques, respectively. In this paper, we discuss the relative advantages of the different methods for detecting 2,4-DAPG producers.

Additional keywords: antibiotics, plant growth-promoting rhizobacteria.
Plant growth-promoting rhizobacteria (PGPR) are root-associated bacteria that have the ability to improve the growth of plants when applied to seeds, soil, or subterranean plant parts (16). Growth promotion occurs as a result of direct stimulation of the plant, inhibition of plant pathogens, or induction of host defense mechanisms against pathogens $(41,42)$. Fluorescent Pseudomonas spp. producing the polyketide antibiotic 2,4-diacetylphloroglucinol (DAPG) are some of the most effective PGPR that control root and seedling diseases. Some well studied strains include $P$. fluorescens CHA0 against black root rot of tobacco, crown and root rot of tomato, Pythium damping-off of cucumber, and take-all of wheat $(8,14,36,40)$; $P$. fluorescens F113 has activity against Pythium damping-off of sugar beet and cyst nematode and soft rot of potato (4,5,10,38); and P. fluorescens Q2-87 and Q8r1-96 suppress take-all of wheat $(12,28,31,44)$. Genetic studies demonstrating a role for 2,4DAPG in biological control have been complemented by the direct isolation of 2,4-DAPG from the rhizosphere $(3,30)$. The 2,4-DAPG biosynthetic locus contains six genes, phlA, phlB, phlC, phlD, phlE, and $p h l F$, coding for the regulation, synthesis, and export of 2,4DAPG (2) and is conserved among 2,4-DAPG-producing pseudomonads isolated from soils worldwide $(7,15,20,33)$. The $p h l D$ gene

Corresponding author: B. B. Landa; E-mail address: bb_landa@mail.wsu.edu

Publication no. P-2001-1205-03R

This article is in the public domain and not copyrightable. It may be freely reprinted with customary crediting of the source. The American Phytopathological Society, 2002. product, which functions in the synthesis of the 2,4-DAPG-precursor monoacetylphloroglucinol, has remarkable homology with members of the chalcone synthase/stilbene synthase family of plant enzymes $(2,34)$.

Whole-cell repetitive sequence-based polymerase chain reaction (rep-PCR) with the BOXA1R primer set (BOX-PCR) distinguished over a dozen distinct genotypes (A through $\mathrm{N}$ ) within a worldwide collection of 2,4-DAPG-producing fluorescent Pseudomonas spp. (23), and results from cluster analysis of polymorphisms within phlD correlated very well with these groupings (20). Random amplified polymorphism DNA analyses with a variety of primers revealed even greater genetic diversity among 2,4-DAPG producers than found by rep-PCR (20,32). 2,4-DAPG producers vary considerably in biocontrol activity and root colonizing ability, and only now is the relationship between these traits and strain genotype being revealed. For example, strains belonging to the BOX-PCR-defined D genotype often are dominant in the rhizosphere of wheat grown in fields that have experienced wheat monoculture or undergone take-all decline (37). Raaijmakers and Weller (32) demonstrated that the D genotype strain Q8r1-96 colonized the wheat rhizosphere substantially better than the B genotype strain Q2-87 and the L genotype strain 1M1-96 when the bacteria were added to the soil and multiple cycles of wheat were grown.

The process of root colonization (47) remains an important topic of research, because PGPR must establish and maintain a minimum threshold population size in the rhizosphere to be effective $(31,32)$. However, with few exceptions, PGPR initially estab- 
lish high population densities and decline with time and distance from the inoculum source, comprising a progressively smaller proportion of the total rhizosphere microflora $(1,17,18,45,47)$. To improve PGPR establishment, spread and survival in the rhizosphere environment, studies continue on the effects of soil factors and host genotype on colonization and the traits and genes that contribute to rhizosphere competence $(6,21,39,47)$.

Detecting introduced PGPR is challenging, especially when they are at low densities, because of the enormous background populations of other microorganisms. In addition, some indigenous bacteria may be genetically similar to the introduced strain. Strains with spontaneous or introduced antibiotic resistance (e.g., rifampicin and streptomycin) or introduced genetic markers (e.g., lacZY, lux, xylE, etc.) commonly have been used in studies of root colonization $(17,18,29,45)$. Techniques such as immunofluorescent colony staining (IFC) (18), which detect intrinsic characteristics, do not require genetic modification of the PGPR and often can be used without selective media. To detect and quantify populations of 2,4-DAPG-producing fluorescent Pseudomonas spp., Raaijmakers et al. (33) developed genetic probes and primers specific for sequences within phlD. Following selection of putative $p h l D^{+}$colonies via colony hybridization, PCR primers Phl2a and $\mathrm{Phl} 2 \mathrm{~b}$ were used to confirm that a colony was $p h l D^{+}$(containing phlD sequence). Recently, McSpadden Gardener et al. (22) developed a phlD-specific PCR-based dilution endpoint assay for quantifying 2,4-DAPG producers, which involves incubating aliquots of dilutions of root washings and identifying the last dilution in which a positive signal for phlD occurs. A significant advantage of this method is that restriction fragment length polymorphisms (RFLP) analysis can be used to determine the dominant $p h l D^{+}$genotype present in an environmental sample. In addition, efforts to isolate novel 2,4-DAPG-producing biocontrol strains can be targeted to the specific samples in which the gene was detected.

The objective of this study was to determine the effect of genotype on the enumeration of 2,4-DAPG producers from the wheat rhizosphere. We compared three methods for detecting and quantifying the culturable population of introduced 2,4-DAPG producers: traditional dilution plating on selective agar media, colony hybridization followed by PCR, and phlD-specific dilution endpoint PCR. In doing so, we were interested in determining the relative strengths and weaknesses of each approach to quantifying phlD $D^{+}$bacteria introduced into the rhizosphere of wheat.

\section{MATERIALS AND METHODS}

Soil. The physical and chemical properties of the Shano sandy loam soil (Quincy virgin) used in this study were described previously (33). The soil was collected near Quincy, WA, in May 2000 from a noncropped site that was covered by native vegetation. The soil was taken from the upper $30 \mathrm{~cm}$ of the soil profile, air dried, and passed through a mesh screen $(0.5 \mathrm{~cm})$ prior to use. This soil was selected because indigenous 2,4-DAPG-producing fluorescent Pseudomonas spp. occur at or below population densities of $10^{4} \mathrm{CFU} / \mathrm{g}$ of root when wheat is grown $(30,31,33)$.

Bacterial strains and growth media. Ten phlD $P$. fluorescens strains were used in this study. Strains Q2-87, W4-4, W2-6, L5.1-96, Q8r1-96 (22,23,31,32), and Q8r2-96 (J. M. Raaijmakers and D. M. Weller, unpublished data) were isolated from roots of wheat grown in two different take-all decline soils in Washington State. Strain 1M1-96 was isolated from the rhizosphere of wheat grown in a soil near Mount Vernon, WA, that is suppressive to Fusarium wilt of pea (32). P. fluorescens CHA0, Pf-5, and F113 originally were isolated from the rhizospheres of tobacco $(14,40)$, cotton (13), and sugar beet $(25,38)$, respectively. These strains are from six different geographic locations and include five distinct genotypes (A, B, D, K, and L) previously defined by BOX-PCR (23) and RFLP analysis of phlD (20). Four strains of the D geno- type were included because this genotype is most commonly found in wheat fields. These strains are referred to collectively as phlD ${ }^{+}$strains. P. fluorescens 2-79 (46) does not contain phlD and was used as a negative control in PCR and colony hybridization assays.

All chemicals were obtained from Sigma Chemical, Co., St. Louis, unless noted otherwise. All strains were rifampicin-resistant and were routinely cultured on a modified semiselective medium for Pseudomonas spp., which consisted of one-third strength King's B medium (1/3× KMB) supplemented with ampicillin $(40 \mu \mathrm{g} / \mathrm{ml})$, chloramphenicol $(13 \mu \mathrm{g} / \mathrm{ml})$, and cycloheximide $(100 \mu \mathrm{g} / \mathrm{ml})\left(1 / 3 \times \mathrm{KMB}^{+++}\right)(22)$ at $25^{\circ} \mathrm{C}$. Introduced and indigenous rhizosphere bacteria were isolated on $1 / 3 \times \mathrm{KMB}^{+++}$ or $1 / 3 \times \mathrm{KMB}^{+++}$supplemented with rifampicin $(100 \mu \mathrm{g} / \mathrm{ml})(1 / 3 \times$ $\mathrm{KMB}^{+++}$rif). When needed, these media were solidified with $17 \mathrm{~g} /$ liter of agar. Frozen stock cultures of all strains were stored in $1 / 3 \times \mathrm{KMB}^{+++}$plus $18 \%$ glycerol and $50 \mu \mathrm{g}$ of rifampicin per $\mathrm{ml}$ at $-80^{\circ} \mathrm{C}$.

Bacterial inoculation and plant cultivation. Bacterial inocula were grown on $1 / 3 \times \mathrm{KMB}^{+++}$agar for $48 \mathrm{~h}$ at $25^{\circ} \mathrm{C}$. Cells were washed in water by centrifugation $(\mathrm{J} 2-21 \mathrm{M}$; Beckman Coulter Inc., Palo Alto, CA) at $8,000 \times g$ for $10 \mathrm{~min}$ and suspended in sterile distilled water. Cell densities were assessed by their turbidity $\left(\mathrm{OD}_{600 \mathrm{~nm}}\right)$ with a microplate spectrophotometer (MR5000; Dynatech Laboratories, Burlington, MA), diluted in water, and introduced into the soil in a $1 \%$ methylcellulose suspension (100 ml of suspension per 1,000 $\mathrm{g}$ of soil) to give approximately $10^{4} \mathrm{CFU} / \mathrm{g}$ fresh weight of soil. The actual density of each strain established in the soil was determined by assaying 0.5 -g portions of soil using the phlD-specific PCR-based dilution end point method (22).

Wheat was grown as described by Raaijmakers and Weller (31). Twelve wheat seeds (cv. Penawawa) were sown in square PVC pots $(8 \mathrm{~cm}$ high, $7.5 \mathrm{~cm}$ wide) containing $200 \mathrm{~g}$ of sieved raw Quincy virgin soil inoculated with the individual bacterial isolates. Seeds were covered with a $1-\mathrm{cm}$ layer of noninoculated soil. The control treatment consisted of soil inoculated with a $1 \%$ methylcellulose suspension. Each treatment was replicated six times with each pot serving as a replicate. Pots received $50 \mathrm{ml}$ of water supplemented with metalaxyl (Novartis, Greensboro, NC) at $2.5 \mathrm{mg} / \mathrm{ml}$ of active ingredient after sowing to control Pythium root rot. Plants were grown in a controlled environment chamber at $15 \pm 1^{\circ} \mathrm{C}, 40$ to $60 \%$ relative humidity with a 12 -h photoperiod. Pots were watered at 2-day intervals and twice a week received $50 \mathrm{ml}$ of a Miracle-Grow solution 15-30-15 (Scotts Miracle-Gro Products, Port Washington, NY). Two similar independent experiments were conducted. In experiment I, after 3 weeks of growth, the shoots of the plants were excised at the soil surface, and the soil and associated root system from a single pot were decanted into a plastic bag and mixed by shaking. Then, the soil was returned to the same pot and replanted with 12 wheat seeds. In experiment II, soil was not replanted. At the end of each experiment, six plants were selected randomly from each replicate pot to determine the population size of the introduced strain. Root systems were removed from soil and gently shaken to remove loosely adhering soil.

Enumeration of bacteria from the rhizosphere. Samples $(0.5 \mathrm{~g}$ of soil or roots with adhering rhizosphere soil) were placed in $50-\mathrm{ml}$ screw-cap centrifuge tubes with $10 \mathrm{ml}$ of sterile distilled water. The samples were shaken vigorously for $1 \mathrm{~min}$ on a Vortex mixer, and sonicated in an ultrasonic cleaner (Bransonic 521; Branson, Shelton, CT) for $1 \mathrm{~min}$. The number of $p h l D^{+}$cells was estimated by three different methods: (i) $100 \mu \mathrm{l}$ of the wash solution was serially diluted (1:10) in 1.5-ml Eppendorf tubes prefilled with $900 \mu \mathrm{l}$ of sterile distilled water and plated in duplicate onto $1 / 3 \times \mathrm{KMB}^{+++}$agar plates for subsequent colony hybridization and PCR; (ii) $100 \mu \mathrm{l}$ of the wash solution was serially diluted (1:10) in 1.5-ml Eppendorf tubes prefilled with $900 \mu \mathrm{l}$ of sterile distilled 
water and plated in duplicate onto $1 / 3 \times \mathrm{KMB}^{+++}$rif agar plates; and (iii) $100 \mu \mathrm{l}$ of the wash solution was serially diluted (1:3) in a 96-well microtiter plate (Costar, Corning, NY) prefilled with $200 \mu \mathrm{l}$ of sterile distilled water and $50 \mu \mathrm{l}$ of each dilution was transferred to a well of a 96-well plate containing fresh $1 / 3 \times$ $\mathrm{KMB}^{+++}$rif broth (22). Agar plates and microtiter plates were incubated at room temperature $\left(23 \pm 1^{\circ} \mathrm{C}\right)$ in the dark, and bacteria growing on $1 / 3 \times \mathrm{KMB}^{+++}$and $1 / 3 \times \mathrm{KMB}^{+++}$rif were assessed after $48 \pm 4 \mathrm{~h}$ and $72 \pm 4 \mathrm{~h}$, respectively. Growth in the microtiter plates was assayed spectrophotometrically; an optical density at $600 \mathrm{~nm}\left(\mathrm{OD}_{600}\right)$ of $\geq 0.05$ was scored as positive (22). Representative colonies growing on $1 / 3 \times \mathrm{KMB}^{+++}$rif plates (at least 12 colonies per treatment) and aliquots from the terminal dilution from the microtiter plates were confirmed to contain phlD by PCR, and the genotype of $p h l D^{+}$strains was determined by RFLP analysis $(20,22)$. The density of total culturable heterotrophic bacteria in each sample was determined by transferring $50-\mu \mathrm{l}$ aliquots from the serially diluted (1:3) washings into 96-well microtiter plates containing 1/10th-strength tryptic soy broth (TSB; $3 \mathrm{~g}$ of Difco TSB per liter) (19) supplemented with cycloheximide $(100 \mu \mathrm{g} / \mathrm{ml})\left(1 / 10 \times \mathrm{TSB}^{+}\right)$. The terminal dilution in the microplate showing positive growth $\left(\mathrm{OD}_{600} \geq 0.05\right)$ was used to calculate the total population size of bacteria of a sample.

Colony and dot-blot hybridization. Colony hybridization was performed as described by Raaijmakers et al. (33) with some modifications. Briefly, after plates of $1 / 3 \times \mathrm{KMB}^{+++}$were incubated for 2 days, bacterial colonies were transferred to Hybond- ${ }^{+}$ membranes (Amersham, Little Chalfont, UK) by standard methods (35), air dried, and baked for $1 \mathrm{~h}$ at $80^{\circ} \mathrm{C}$ in a vacuum oven. To remove bacterial debris, the membranes were washed for $1 \mathrm{~h}$ at $42^{\circ} \mathrm{C}$ in a solution containing $2 \times \operatorname{SSPE}\left(20 \mathrm{mM} \mathrm{NaH}{ }_{2} \mathrm{PO}_{4}[\mathrm{pH}\right.$ 7.4], $0.36 \mathrm{M} \mathrm{NaCl}$, and $2 \mathrm{mM}$ EDTA), $0.1 \%$ sodium dodecyl sulfate (SDS), and pronase $(100 \mu \mathrm{g} / \mathrm{ml})$, and washed again for $1 \mathrm{~h}$ at $56^{\circ} \mathrm{C}$ in $2 \times \mathrm{SSPE}$ and $0.1 \%$ SDS. Hybridization was performed under high stringency conditions by methods similar to those described previously (33). The phlD-probe consisted of the 629-bp DNA fragment amplified by PCR with primers B2BF and BPR4 (22) from P. fluorescens Q8r1-96 and was generated by randomprimed labeling with the nonradioactive digoxigenin (DIG) system (Boehringer Mannheim, Mannheim, Germany). This probe was used because primers B2BF and BPR4 amplify phlD more efficiently from all of the known $p h l D^{+}$strains than primers Phl2a and $\mathrm{Phl} 2 \mathrm{~b}$ originally designed by Raaijmakers et al. (33). The hybridized probes were subjected to immunodetection with antiDIG-AP-Fab fragments, and $p h l D^{+}$colonies were visualized with the colorimetric substrates nitroblue tetrazolium salt and 5-bromo4-chloro-3-indolylphosphate according to the protocols provided by the supplier (Boehringer). Approximately $10 \%$ of the positive colonies of fluorescent Pseudomonas strains per filter (at least 12 colonies per treatment) were isolated and purified on $1 / 3 \times$ $\mathrm{KMB}^{+++}$agar plates. As a quality check of the colony hybridization, whole-cell genomic DNA from isolated positive colonies was amplified by PCR with primers B2BF and BPR4 and the amplification product was subjected to RFLP analysis to confirm the $p h l D^{+}$genotype $(20,22)$. Additionally, a $1 / 3 \times \mathrm{KMB}^{+++}$agar plate containing single colonies from a pure culture of each Pseudomonas strain was included as a quality check to compare the effectiveness of the colony hybridization among the different phlD ${ }^{+}$genotypes (strain-control filter).

Total DNA from all $10 p h l D^{+}$strains and control $p h l D^{-}$strain were isolated and purified according to the Marmur procedure (11), diluted with deionized water, and adjusted to approximately $100 \mathrm{ng} / \mu \mathrm{l}$ with a Versafluor fluorometer (Bio-Rad Laboratories, Hercules, CA). DNA samples $(1 \mu \mathrm{g})$ were serially diluted $(1: 10)$ with a Finnpipette micro volume multichannel pipettor, and DNA samples ( $1 \mu \mathrm{g}$ to $1 \mathrm{pg}$ ) or deionized water were arrayed on Hybond- $\mathrm{N}^{+}$membranes with a Bio-Dot microfiltration unit (BioRad) according to manufacturer's recommendations. Total DNA was denatured for $10 \mathrm{~min}$ at $100^{\circ} \mathrm{C}$, and cooled on ice before dotblotting on membranes. Treated membranes were allowed to dry, and were baked in a vacuum oven for $1 \mathrm{~h}$ at $80^{\circ} \mathrm{C}$. Hybridization and immunodetection were performed by methods similar to those described previously.

PCR amplifications and RFLP analysis. The oligonucleotide primers B2BF and BPR4 (22) were synthesized by Operon Technologies (Alameda, CA). DNA isolation was carried out directly from whole-cell cultures frozen at $-80^{\circ} \mathrm{C}$ for a minimum of $1 \mathrm{~h}$ in either $1 / 3 \times \mathrm{KMB}^{+++}$rif medium or sterile distilled water. PCR amplifications and RFLP analyses of phlD sequences were performed as described previously (22). Briefly, amplification was carried out in a $25-\mu \mathrm{l}$ reaction volume containing $2.5 \mu \mathrm{l}$ of thawed whole-cell template. Amplifications were performed with a PTC200 thermal cycler (MJ Research Inc., Watertown, MA), and the resulting PCR products were separated in $1.5 \%$ agarose gels in $0.5 \times$ Tris-borate-EDTA (TBE) buffer at $125 \mathrm{~V}$ for $2.5 \mathrm{~h}$. For RFLP analyses, $8 \mu \mathrm{l}$ of a PCR reaction was digested in a total volume of $30 \mu \mathrm{l}$ with 10 units of the HaeIII digestion enzyme (New England Biolabs Inc., Beverly, MA) as previously described (22). Reactions were incubated at $37^{\circ} \mathrm{C}$ for $3 \mathrm{~h}$ and stored at $-20^{\circ} \mathrm{C}$. Digestion products were separated on $2 \%$ agarose gels in $0.5 \times \mathrm{TBE}$ buffer for $3 \mathrm{~h}$ at $140 \mathrm{~V}$. Banding patterns were visualized by ethidium bromide staining and scored by comparison to a 100-bp ladder. Gel images were stored as .tif files with a Kodak DC120 digital imaging system (Kodak, Rochester, NY). The RFLP patterns generated by digestion with HaeIII were sufficient to distinguish Box A, B, D, K, and L genotypes used in this study (22).

Data analysis. All bacterial treatments were arranged in a randomized complete block design. The experiment was performed twice. Data were analyzed using STATISTIX (version 7.0, Analytical Software, St. Paul, MN). Population data were tested for normality by the Shapiro-Wilk test. All population data were converted to log CFU/gram fresh weight of soil or root to obtain normal distributions. Percent values were arcsine square roottransformed before data analysis to normalize the variance. Differences between treatments in population densities were determined by standard analysis of variance, and mean comparisons among treatments were performed by Fisher's protected least significant difference test at $P=0.05$, or the two-sampled Mann-Whitney test. Similarity between experiments was tested by preliminary analysis of variance with experimental runs as blocks and Barlett's test of equal variances allowed to combine data for analyses.

Regression analyses were performed on population densities of 2,4-DAPG-producing $P$. fluorescens determined by the three different techniques. Coefficient of determination $\left(R^{2}\right)$, the mean square error, and the standard error associated with the estimated parameter were used to evaluate the appropriateness of the linear model to describe the data. Student's $t$ test was used to determine the significance of the slope and intercept. When the intercept was not significantly different from zero $(P \geq 0.05)$, the model was forced through the origin. A confidence interval was used to determine whether the slope of the regression model was significantly different (confidence level of $95 \%$ ) from 1.

\section{RESULTS}

The detection limits of the 10 strains of 2,4-DAPG-producing

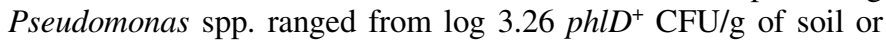
fresh root weight for the phlD-specific PCR-based assay to log 4.0 $\mathrm{phlD}^{+} \mathrm{CFU} / \mathrm{g}$ of fresh root weight for dilution plating and colony hybridization. The detection limit for the total bacterial population was $\log 2.78 \mathrm{CFU} / \mathrm{g}$ of soil or fresh root weight. No $\mathrm{phlD}^{+}$amplification was obtained in the noninoculated methylcellulose control. Initial population sizes of total bacteria in the soil $1 \mathrm{~h}$ after introduction of $p h l D^{+}$strains did not differ significantly $(P \geq 0.05)$ 
and ranged from $\log 5.94$ to $6.48 \mathrm{CFU} / \mathrm{g}$ of soil. Population sizes of the $p h l D^{+}$strains introduced into the soil also did not differ significantly $(P \geq 0.05)$ and ranged from $\log 4.09$ to $4.45 \mathrm{phlD^{+ }}$ $\mathrm{CFU} / \mathrm{g}$ of soil (Table 1). Introduced $p h l D^{+}$strains comprised from 0.98 to $6.38 \%$ of the total culturable heterotrophic bacteria in the soil. Strain Q8r2-96 comprised a significantly greater portion of the total bacterial population than the other strains (Table 1).

After 3 weeks of growth, population densities of total bacteria in the rhizosphere differed significantly $(P=0.039)$ among the treatments and ranged from $\log 6.99$ to $8.06 \mathrm{CFU} / \mathrm{g}$ of fresh root. Population sizes of the phlD ${ }^{+}$strains established in the wheat rhizosphere ranged from $\log 6.18$ to $7.75 \mathrm{phlD}^{+} \mathrm{CFU} / \mathrm{g}$ fresh weight of root, depending of the bacterial treatment (Table 1). The population densities of $P$. fluorescens $\mathrm{Pf}-5$ (A genotype) and W4-4 (L genotype) were significantly lower $(P<0.001)$ than the densities of the other $p h l D^{+}$strains. The percentage of the total bacterial population consisting of the phlD ${ }^{+}$strains ranged from 24.92 to $90.12 \%$ and differed significantly $(P=0.007)$ among strains (Table 1).

Digestion of the 629-bp phlD amplification products with HaeIII demonstrated that the RFLP pattern of the phlD ${ }^{+}$strains detected were identical to those introduced in the rhizosphere (data not shown). The phlD gene was not detected from rhizosphere samples of the negative control treatment, indicating that indigenous populations of 2,4-DAPG-producing pseudomonads were below the detection limit $\left(<\log 3.26 \mathrm{phlD}^{+} \mathrm{CFU} / \mathrm{g}\right.$ of fresh root weight).

Regression analysis demonstrated a significant $(P<0.0001)$ linear relationship between the population densities of the 10 phlD ${ }^{+}$strains detected by colony hybridization followed by PCR and dilution plating on $1 / 3 \times \mathrm{KMB}^{+++}$rif. Because the intercept was not significantly different from zero $(P=0.257)$, the model was forced through the origin, resulting in a regression line with a slope of 0.99 (Fig. 1). From this, we concluded that both methods were equally effective at detecting introduced 2,4-DAPG producers in the wheat rhizosphere. All of the rifampicin-resistant colonies isolated on $1 / 3 \times \mathrm{KMB}^{+++}$rif plates were confirmed by
RFLP analysis of the phlD amplification products to be the same genotype as originally introduced into the soil.

The phlD probe generated from strain Q8r1-96 used in the colony hybridization procedure hybridized more strongly with colonies of strains belonging to the D genotype (W2-6, L5.1-96, Q8r1-96, and Q8r2-96) and the K genotype (strain F113) than to strains of the A genotype (Pf-5 and CHA0), B genotype (Q2-87), and L genotype (1M1-96 and W4-4) (Fig. 2). Colonies of the K and $\mathrm{D}$ genotypes showed a stronger reaction (detected as a dark blue) compared with the weak signal (lighter blue) obtained with colonies of A, B, and L genotype strains (Fig. 2). This was true for both colonies on strain-control filters and those blotted from $1 / 3 \times$ $\mathrm{KMB}^{+++}$agar inoculated with roots washes. Colonies of $P$. fluorescens 2-79 were not detected on control filters (Fig. 2), but occasionally a background color was observed similar to those developed from other bacteria that do not contain phlD present in the rhizosphere washes. All the colonies putatively identified as phlD ${ }^{+}$by colony hybridization on plates from the CHA0, W2-6, L5.1, Q8r1, Q8r-2, and F113 treatments were confirmed to carry phlD DNA by PCR (Fig. 2). However, only 8.3, 83.3, 91.7, and $75.0 \%$ of the hybridizing colonies from the Pf-5, Q2-87, 1M1-96, and W4-4 treatments, respectively, were confirmed to be $p h l D^{+}$ positive by PCR. Thus, colony hybridization without PCR overestimated the actual densities of some genotypes of 2,4-DAPG producers in the wheat rhizosphere. This problem of false positives was exacerbated when the population density of a strain was low in comparison to the total number of culturable bacteria (data not shown). The weak hybridization signals from the colonies of Pf-5 and W4-4 made it difficult to differentiate the $p h l D^{+}$colonies from the background of total bacteria. Nonetheless, hybridization results were reproducible when the experiment was repeated.

To test the possibility of probe specificity for $p h l D^{+}$genotypes, total DNA from all 10 phlD ${ }^{+}$strains and the control strain (2-79) were purified and arrayed on Hybond- $\mathrm{N}^{+}$membranes. DNA from strains belonging to genotypes $\mathrm{B}, \mathrm{D}, \mathrm{K}$, and $\mathrm{L}$ showed a consistently strong signal when treated with the phlD-probe, whereas DNA from the A genotype strains (Pf-5 and CHA0) provided a

TABLE 1. Population densities of introduced 2,4-diacetylphloroglucinol (DAPG)-producing Pseudomonas fluorescens strains in Quincy virgin soil

\begin{tabular}{|c|c|c|c|c|c|c|}
\hline \multirow[b]{2}{*}{ Treatment } & \multicolumn{3}{|c|}{$\log (\mathrm{CFU} / \mathrm{g}$ of soil $) \pm \mathrm{SE}^{w}$} & \multicolumn{3}{|c|}{$\log (\mathrm{CFU} / \mathrm{g}$ of fresh root $) \pm \mathrm{SE}^{\mathrm{w}}$} \\
\hline & $\begin{array}{c}\text { phlD }{ }^{+} \text {PCR-based } \\
\text { assay }^{\mathrm{x}}\end{array}$ & Total bacteria ${ }^{\mathrm{y}}$ & $\begin{array}{l}p h l D^{+} / \text {total } \\
\text { bacteria }(\%)\end{array}$ & $\begin{array}{c}\text { phlD }{ }^{+} \text {PCR-based } \\
\text { assay }^{\mathrm{x}}\end{array}$ & Total bacteria ${ }^{\mathrm{y}}$ & $\begin{array}{l}p h l D^{+} / \text {total } \\
\text { bacteria }(\%)\end{array}$ \\
\hline Control & $<3.26^{\mathrm{z}}$ & $6.29 \pm 0.12$ & $<0.12 \mathrm{c}$ & $<3.26^{\mathrm{z}}$ & $7.21 \pm 0.14 \mathrm{~cd}$ & $<0.07 \mathrm{c}$ \\
\hline Pf-5 & $4.09 \pm 0.11$ & $5.94 \pm 0.09$ & $2.36 \mathrm{~b}$ & $6.18 \pm 0.17 \mathrm{c}$ & $7.46 \pm 0.28 \mathrm{a}-\mathrm{d}$ & $24.92 \mathrm{bc}$ \\
\hline $\mathrm{CHAO}$ & $4.45 \pm 0.11$ & $6.36 \pm 0.11$ & $1.65 \mathrm{~b}$ & $7.17 \pm 0.12 b$ & $7.65 \pm 0.15 \mathrm{a}-\mathrm{c}$ & $48.15 \mathrm{ab}$ \\
\hline Q2-87 & $4.21 \pm 0.09$ & $6.18 \pm 0.16$ & $1.61 \mathrm{~b}$ & $7.13 \pm 0.16 b$ & $7.69 \pm 0.39 \mathrm{a}-\mathrm{c}$ & $56.79 \mathrm{ab}$ \\
\hline F113 & $4.33 \pm 0.09$ & $6.36 \pm 0.14$ & $1.58 \mathrm{~b}$ & $7.47 \pm 0.23 \mathrm{ab}$ & $7.95 \pm 0.19 a b$ & $90.12 \mathrm{ab}$ \\
\hline $1 M 1-96$ & $4.15 \pm 0.12$ & $6.42 \pm 0.09$ & $0.98 \mathrm{bc}$ & $6.95 \pm 0.23 \mathrm{~b}$ & $7.35 \pm 0.20 \mathrm{~b}-\mathrm{d}$ & $61.73 \mathrm{ab}$ \\
\hline W4-4 & $4.39 \pm 0.08$ & $6.18 \pm 0.09$ & $2.06 \mathrm{~b}$ & $6.27 \pm 0.36 \mathrm{c}$ & $6.99 \pm 0.33 \mathrm{~d}$ & $32.10 \mathrm{bc}$ \\
\hline W2-6 & $4.45 \pm 0.11$ & $6.48 \pm 0.14$ & $1.23 \mathrm{~b}$ & $7.12 \pm 0.10 b$ & $7.69 \pm 0.17 \mathrm{a}-\mathrm{c}$ & $32.10 \mathrm{bc}$ \\
\hline L5.1-96 & $4.27 \pm 0.09$ & $6.24 \pm 0.12$ & $1.61 \mathrm{~b}$ & $7.76 \pm 0.14 \mathrm{a}$ & $7.84 \pm 0.14 \mathrm{a}-\mathrm{c}$ & $88.89 \mathrm{a}$ \\
\hline Q8r1-96 & $4.21 \pm 0.09$ & $6.12 \pm 0.18$ & $2.12 \mathrm{~b}$ & $7.51 \pm 0.22 \mathrm{ab}$ & $8.06 \pm 0.21 \mathrm{a}$ & $54.32 \mathrm{ab}$ \\
\hline Q8r2-96 & $4.45 \pm 0.11$ & $6.00 \pm 0.11$ & $6.38 \mathrm{a}$ & $7.10 \pm 0.20 b$ & $7.89 \pm 0.14 \mathrm{ab}$ & $62.96 \mathrm{ab}$ \\
\hline
\end{tabular}

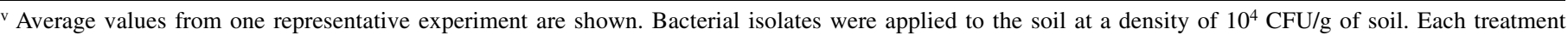
consisted of six pots with 12 plants per pot. Plants were grown for 3 weeks in the greenhouse at $15 \pm 1{ }^{\circ} \mathrm{C}$, 40 to $60 \%$ relative humidity with a 12 -h photoperiod. Means in a column followed by the same letter are not significantly different $(P=0.05)$ according to Fisher's protected least significant difference. Only significant differences are shown. Colonization data were converted to log CFU per gram of fresh weight of soil or root, and percent values were arcsine transformed before data analysis.

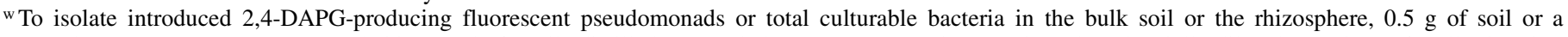
complete root system were suspended in $10 \mathrm{ml}$ of sterile distilled water, shaken on a vortex mixer, sonicated, and serially diluted (1:3) in a 96-well microtiter plate prefilled with $200 \mu \mathrm{l}$ of sterile distilled water per well. SE = standard error.

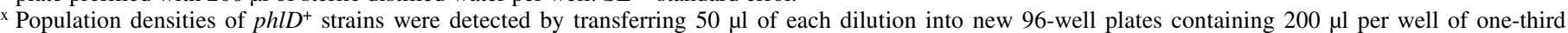
strength King's B medium supplemented with rifampicin $\left(1 / 3 \times \mathrm{KMB}^{+++}\right.$rif). The plates were incubated at room temperature in the dark for $72 \pm 4 \mathrm{~h}$. Bacterial growth in the 96-well plates was assayed spectrophotometrically; an optical density at $600 \mathrm{~nm}\left(\mathrm{OD}_{600}\right)$ of $\geq 0.05$ was scored as positive (22). Aliquots from the terminal dilution of growth were processed by polymerase chain reaction (PCR) and restriction fragment length polymorphism analyses to confirm the isolate as 2,4-DAPG producer.

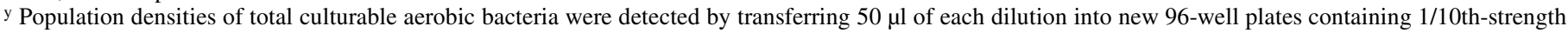
tryptic soy broth supplemented with cycloheximide, and incubated at room temperature in the dark for $48 \pm 4 \mathrm{~h}$. Bacterial growth in the 96 -well plates was assayed spectrophotometrically; an $\mathrm{OD}_{600} \geq 0.05$ was scored as positive.

${ }^{\mathrm{z}}$ phlD ${ }^{+}$strains were not detected. Values presented are detection limit per gram of soil or gram of root. 
weak signal (data not shown). DNA from strain 2-79 gave no signal or a weak signal. The intensity of the observed hybridization signal also varied depending on DNA concentration. In general, a minimum of 10 to $1 \mathrm{ng}$ was required to obtain a detectable signal with the DIG-labeled probe (data not shown).

Regression analysis demonstrated a significant 1-to-1 linear relationship $(P<0.0001)$ between the population densities of the 10 2,4-DAPG-producers in the rhizosphere of wheat as estimated by the phlD-specific PCR-based assay and dilution plating onto $1 / 3 \times \mathrm{KMB}^{+++}$rif agar in each of two experiments. Comparison of the regression lines for each experiment showed homogeneity of residual variances and nonsignificant differences $(P>0.287)$ between the slopes or the intercepts of each linear model alone. Consequently, a common linear regression model was estimated. The intercept of this linear model was not significantly different from zero $(P=0.933)$ so the model was forced through the origin; the slope of the regression line was 0.98 and not significantly different from 1 (Fig. 3A).

Similarly, a significant linear 1-to-1 relationship $(P<0.0001)$ was observed between the population densities of the $10 \mathrm{phlD^{+ }}$ strains detected by the phlD-specific PCR-based dilution endpoint assay and the colony hybridization followed by PCR in each of two experiments. Comparison of regression lines, as described previously, allowed estimation of a common linear model. The intercept was not significantly $(P=0.089)$ different from zero so the model was forced through the origin. The slope of the resulting regression line was 0.98 and not significantly different from 1 (Fig. 3B).

When population densities detected with the phlD-specific PCR-based dilution endpoint assay, colony hybridization, and dilution plating were pooled, analysis of variance indicated that there were small but significant $(P<0.0001)$ differences among techniques and bacterial treatments. The mean $p h l D^{+}$population densities for all the bacterial treatments were $\log 7.46, \log 7.39$, and $\log 7.08 \mathrm{phlD^{+ }} \mathrm{CFU} / \mathrm{g}$ of soil estimated by dilution plating, colony hybridization, and the PCR-based assay, respectively. The slightly lower population densities estimated by the PCR-based assay were due to a significantly $(P=0.05)$ lower estimation of the populations densities of three (CHA0, W2-6, and Q8r2-96) of the 10 studied $p h l D^{+}$strains. Thus, the mean $(n=6)$ population densities for these three strains estimated with the PCR-based assay were significantly $(P<0.041)$ smaller by 7.57 to $9.18 \%$ and 6.42 to $9.44 \%$ compared with population densities detected by the dilution plating or colony hybridization techniques, respectively. Population densities determined by the dilution plating or colony hybridization techniques for all strains did not differ significantly $(P \geq 0.05)$.

\section{DISCUSSION}

During the last 2 decades, considerable effort has been devoted to developing methods to monitor the population dynamics of PGPR in the rhizosphere and bulk soil. Dilution plating on selective media coupled with the use of strains with selectable markers such as antibiotic resistance has been the most commonly used approach. However, the use of this approach to study the rhizosphere competence of multiple PGPR strains can be very labor intensive, especially as related to media preparation and counting colonies. The phlD-specific PCR-based dilution endpoint assay originally described by McSpadden Gardener et al. (22) has substantial advantages compared with dilution plating when studying 2,4-DAPG producers. For example, in our study of 11 bacterial treatments, approximately 400 petri plates and 10 liters of $1 / 3 \times$ $\mathrm{KMB}^{+++}$rif were needed for one sampling, in which duplicate plates were used for each dilution. In contrast, the phlD-specific PCR-based assay required only 22 microtiter plates and approximately $220 \mathrm{ml}$ of $1 / 3 \times \mathrm{KMB}^{+++}$rif broth for the same samples. Furthermore, a single operator can process at least three times as many samples with the PCR-based assay compared with dilution plating. An additional advantage is that once the samples have been processed and incubated, they can be stored at -20 or $-80^{\circ} \mathrm{C}$ and the PCR step completed at a later date.

A key question asked in our study concerned the breadth of the applicability of the phlD-specific PCR-based dilution endpoint assay and whether this method or the dilution plating or colony hybridization were biased for or against a particular genotype. In the original report, McSpadden Gardener et al. (22) demonstrated the recovery of only strains W2-6 and W4-4, D and L genotypes, respectively. Our 10 strains represented five different genotypes isolated from six geographically different locations. We think that the very strong relationship between the population densities detected by dilution plating and the PCR-based assay indicates that the latter method will be broadly applicable. One potential weakness of the technique is that it slightly underestimated the population densities of 3 of the 10 2,4-DAPG-producing fluorescent $P$. fluorescens strains by 6.4 to $9.4 \%$ compared with the other two methods tested. These underestimates were infrequent (i.e., 3 of 10 strains examined), strain-specific, and not correlated to genotype. It seems likely that some $p h l D^{+}$strains simply differ in the degree to which they can be cultured on the solid compared with liquid media used in this study. In any case, these differences of $<10 \%$ can be considered inconsequential in studies of rhizosphere colonization because of the high degree of sample-to-sample variance (i.e., of threefold or more) typically observed in such experiments.

The colony hybridization technique has been used successfully with different approaches $(27,33)$ to isolate and determine the frequency and diversity of indigenous 2,4-DAPG-producing fluorescent Pseudomonas spp. in natural environments. We think that it is the best method to isolate the broadest range of genetically diverse 2,4-DAPG producers from soil and the rhizosphere, especially when information about genomic diversity is not available. In contrast, the phlD-specific PCR-based assay is less versa-

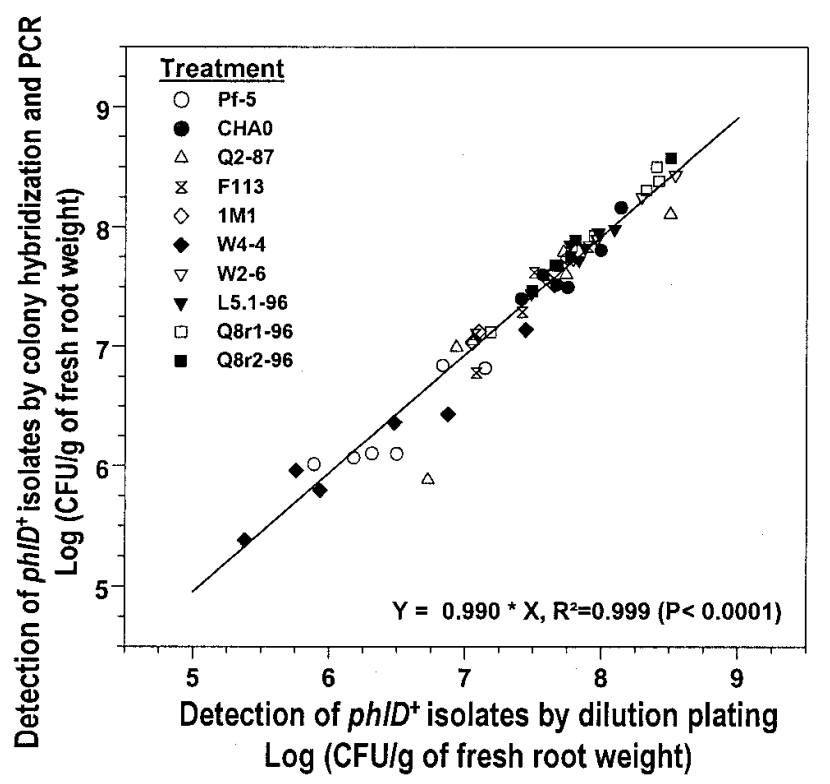

Fig. 1. Comparison of dilution plating onto one-third strength King's B medium supplemented with ampicillin, chloramphenicol, cycloheximide, and rifampicin $\left(1 / 3 \times \mathrm{KMB}^{+++}\right.$rif) and colony hybridization followed by polymerase chain reaction (PCR) for enumeration of the population densities of 2,4-diacetylphloroglucinol producers in the rhizosphere of wheat. Bacteria were introduced into Quincy virgin soil at approximately $10^{4} \mathrm{CFU} / \mathrm{g}$ of soil, and wheat was grown for 3 weeks. A significant $(P<0.0001)$ linear relationship was found between population densities detected by the two techniques. The intercept was not significantly $(P=0.257)$ different from zero so the model was forced through the origin. Each symbol represents the population size detected on a single plant. 


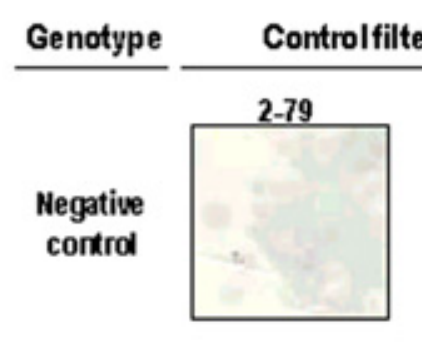

Pi-5

A

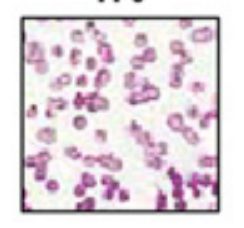

Q2-87

B

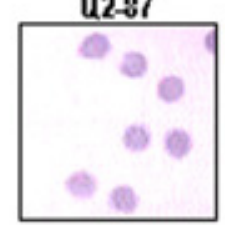

WR-6

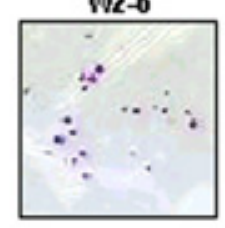

Q⿻r 1-96

D

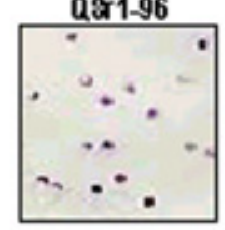

F113

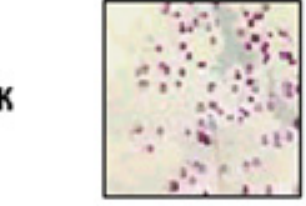

1M1-96

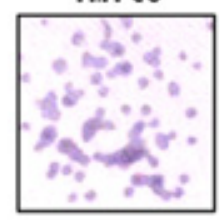

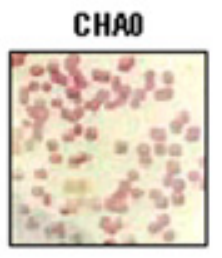
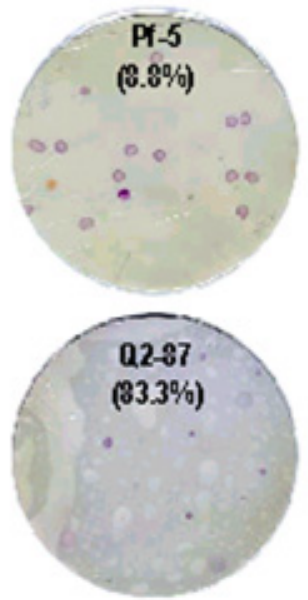

L5.1-96
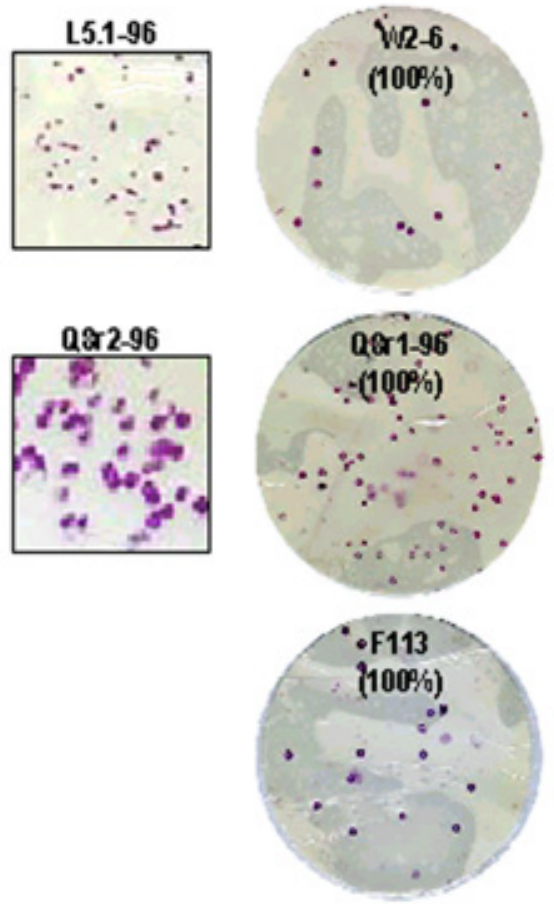

W4-4

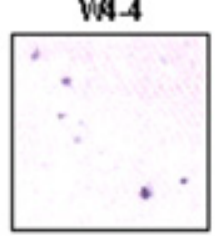

\section{Rhizosphere samples [phiD'ITotal' filter (\%)]}

Control

(nd)
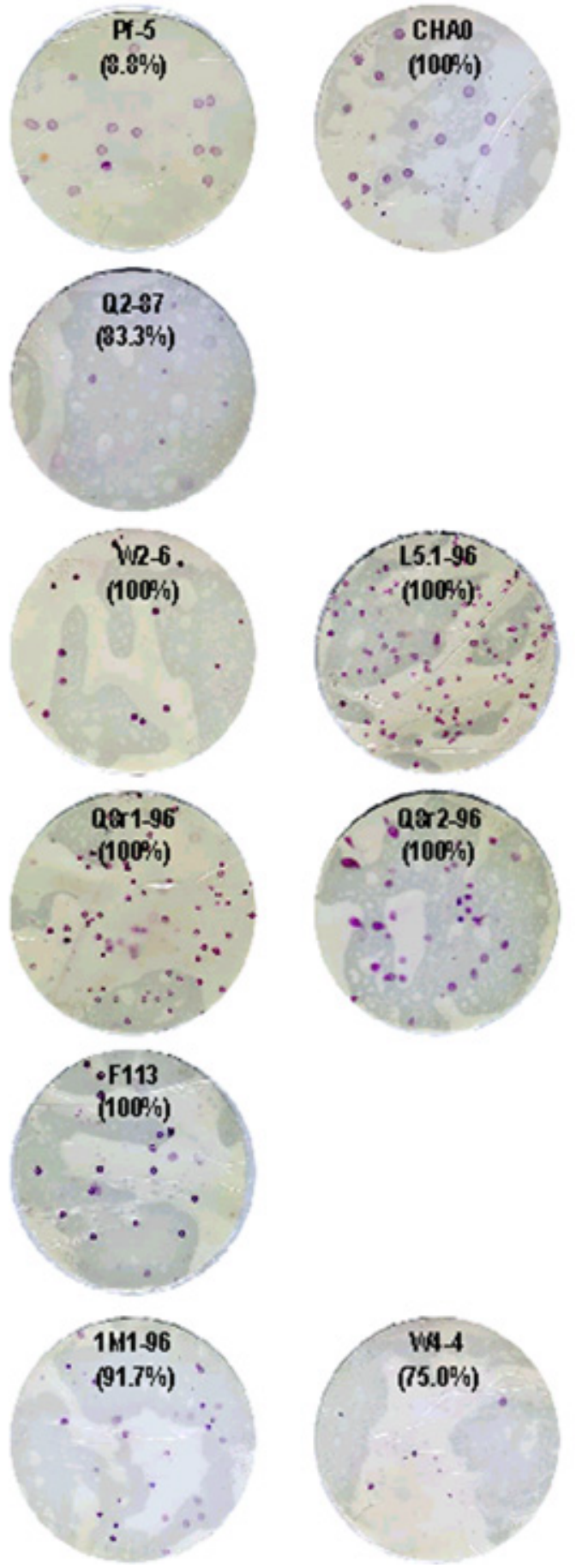

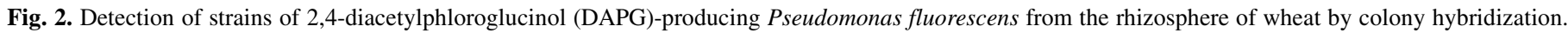

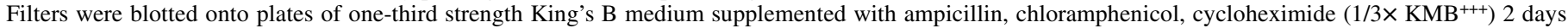

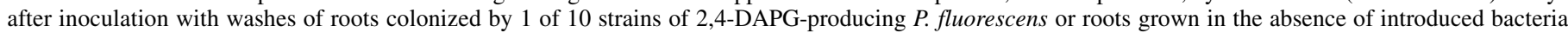

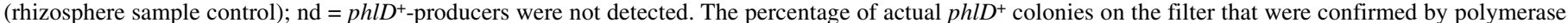

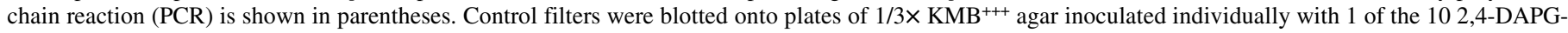

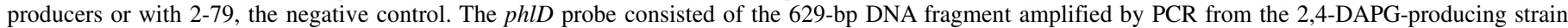
Q8r1-96 (D genotype). Hybridization was conducted under high stringency conditions by standard methods as previously described by Raaijmakers et al. (33). 
tile for isolating the full spectrum of genotypes present in a sample. McSpadden Gardener et al. (22) reported that subdominant genotypes in a sample are not likely detected by RFLP analysis when they comprise less than one-third of the total $p h l D^{+}$ cells (because of the threefold dilution scheme used). Nevertheless, both colony hybridization and the phlD-specific PCR assay share the advantage of permitting the tracking of introduced wildtype 2,4-DAPG producers. Although the results from colony hybridization correlate very well with those of the other two methods, it is not the best approach for conducting detailed studies of the population dynamics of introduced 2,4-DAPG producers. When large numbers of samples need to be processed, colony hybridization simply is too time consuming. The steps in colony hybridization, including colony transfer to the nylon membranes, blotting, washing, hybridization, and immunodetection of $p h l D^{+}$ sequences, are much more sensitive to operator error than the steps in the other two techniques. Another limitation of the colony hybridization technique is that this technique alone overestimates the actual populations of $p h l D^{+}$producers in the rhizosphere, and at least $10 \%$ of the positive colonies per filter need to be purified and checked by PCR to confirm the colony as $p h l D^{+}$. Similarly, Raaijmakers et al. (33) found that at population densities of Q2-87 lower than $10^{5} \mathrm{CFU} / \mathrm{g}$ of root, colony hybridization alone overestimated the actual population density of this strain between 10 to $20 \%$. Durisin et al. (9) found that when high backgrounds of indigenous microflora were present in a milk sample (aerobic plate counts reached from $10^{6}$ to $10^{7} \mathrm{CFU} / \mathrm{g}$ ), the efficiency of colony hybridization was reduced because the target cells (pathogenic yersiniae) could not grow in the presence of competing microflora.

The probe developed originally by Raaijmakers et al. (33) to detect 2,4-DAPG producers by colony hybridization was derived from a PCR fragment amplified from strain Q2-87 by primers $\mathrm{Phl} 2 \mathrm{a}$ and $\mathrm{Phl} 2 \mathrm{~b}$, which were designed with the phlD sequence from Q2-87. Later it was observed that Phl2a and Phl2b did not efficiently amplify phlD from strains belonging to BOX-PCR group C (O. V. Mavrodi, L. S. Thomashow, and D. M. Weller, unpublished data), and the original PCR protocol had to be modified (20). We used a probe amplified from strain Q8r1-96 with primers
B2BF and BPR4, which were designed by McSpadden Gardener et al. (22) after alignment of phlD sequences from five different strains representing four different BOX-PCR genotypes. These primers amplified phlD from all genotypes of 2,4-DAPG producers. Nevertheless, the phlD probe derived from Q8r1-96 by primers $\mathrm{B} 2 \mathrm{BF}$ and BPR4 performed differently in colony hybridization depending on the genotype of the strain detected. Hybridization was strongest with colonies of strains of the $\mathrm{D}$ and $\mathrm{K}$ genotypes. Strains of A, B, and L genotypes gave a weaker signal. In fact, the weakness of the signal of the colonies of Pf-5 and W44 made it difficult to distinguish them from the background. These weak signals must be due, in part, to both genetic and physiological variation within and across defined genotypes.

To determine the extent to which the differences in signal strength obtained during colony hybridization resulted from differences in $p h l D$ sequences, total purified DNA from all $p h l D^{+}$ strains was blotted on Hybond- $\mathrm{N}^{+}$membranes and hybridized according to the same procedure as for colony hybridization. Results from this study showed that strains belonging to genotypes $\mathrm{B}, \mathrm{K}, \mathrm{L}$, and $\mathrm{D}$ gave a similar strong signal. In addition, in all the samples, a signal was detected at DNA concentrations as low as 10 to $1 \mathrm{ng}$. Using a similar procedure, Meghrous et al. (24) needed a minimum of $100 \mathrm{ng}$ of total DNA to discriminate among bacteriocin-producing strains of Lactococcus lactis with a 320-bp DIG-labeled probe. For the B and L genotypes, the differences observed in signal intensity or in the percentage of actual phlD colonies on filters obtained in the colony hybridization could be explained by a combination of different interacting factors not related to phlD sequence. Many factors have been reported to influence probe-target hybridization (11); some of those important in this study may include bacterial density on the filter, colony morphology, resistance of cells to breakage, amount of DNA released and fixed on the filter, and accessibility of phlD probe to the DNA target.

In contrast to the other genotypes, the phlD probe hybridize weakly with DNA from the A genotype strains Pf-5 and CHA0, which we think is due to phlD sequence differences. When phlD sequences obtained from Pf-5, CHA0, Q2-87, 1M1-96, and Q8r196 were aligned using Clustal W, sequences from Pf-5 and CHA0
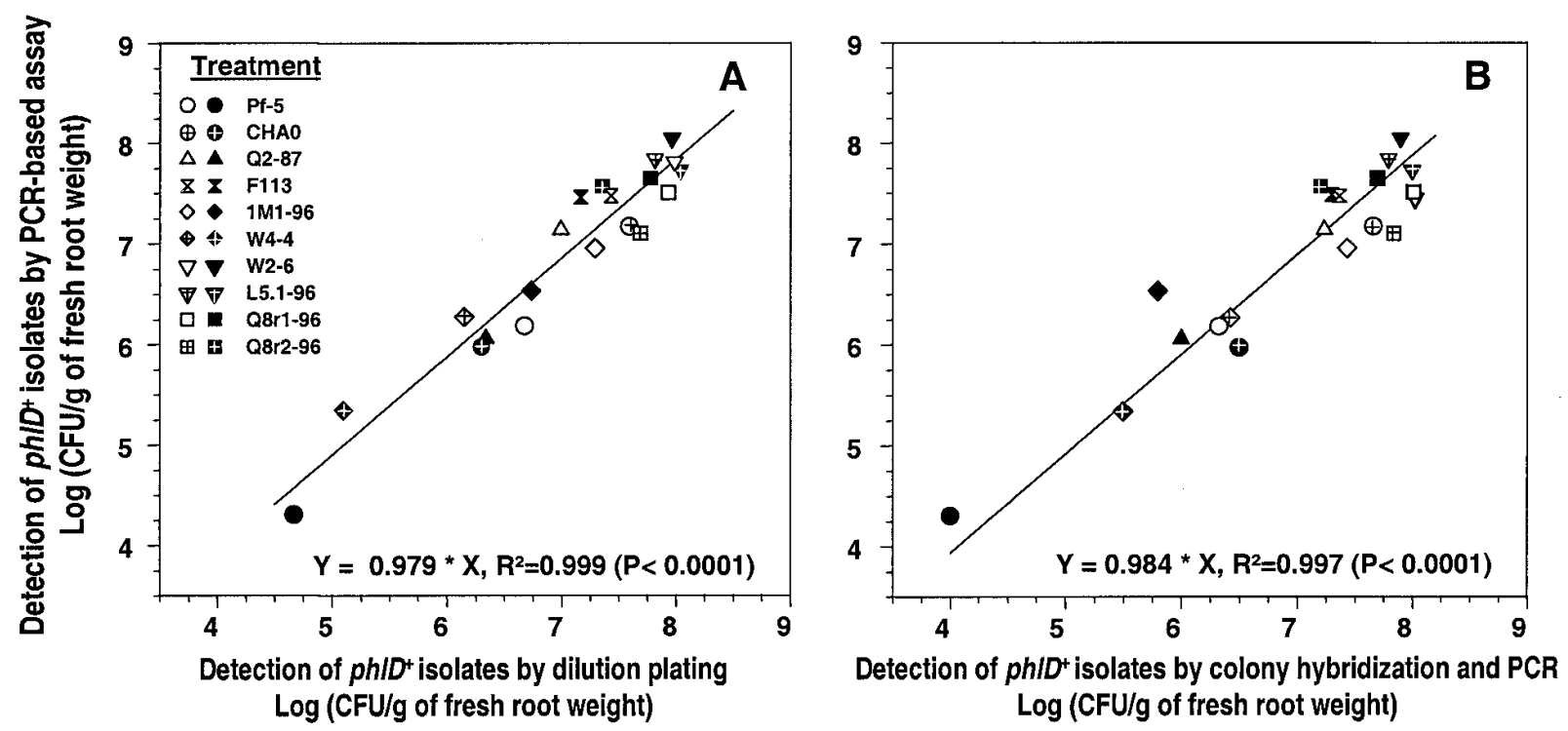

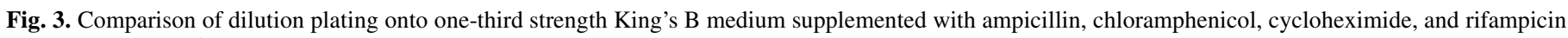

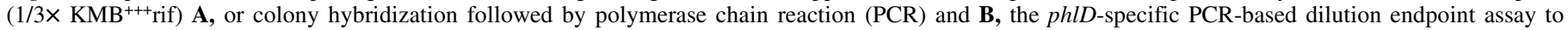

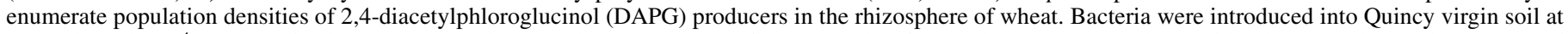

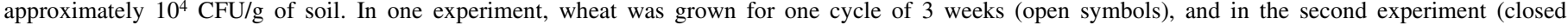

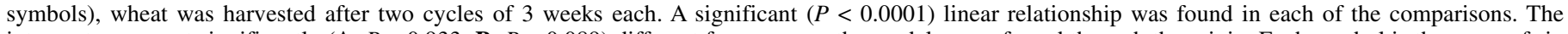

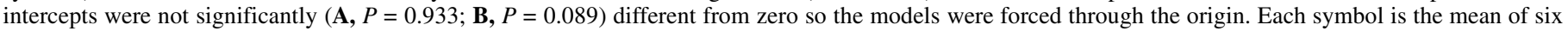
replications, each consisting of a single plant. 
were $98 \%$ identical to each other, but were quite distinct from the sequences obtained from Q2-87, 1M1-96, and Q8r1-96 (22). Using data available in the GenBank database, the percent identity for the Q8r1-96 phlD sequence (probe source) with sequences of F113, 1M1-96, Q2-87, Pf-5, and CHA0 was 95, 94, 87, 78, and $78 \%$, respectively.

It may be possible to sharpen the signals across all genotypes by pooled probes consisting of fragments amplified from several genotypes. Although the probe gave a weak signal with DNA from both CHA0 and Pf-5, the actual number of $p h l D^{+}$colonies detected on filters from rhizosphere washings differed substantially (100 and $8.3 \%$, respectively). This can be attributed to a higher population density of CHA0 and a larger percentage of the total bacteria population.

Mahaffee et al. (18) evaluated three different marking systems, including spontaneous resistance to rifampicin, genetic modification for bioluminescence, and IFC, for their effectiveness in monitoring the population dynamics of the PGPR strain P. fluorescens 89B-27 in the cucumber rhizosphere. Compared with IFC, the use of the other two marking systems underestimated population sizes of strain 89B-27 in the rhizosphere. However, when the rhizosphere population size of the rifampicin-resistant mutant (R34) and wild-type strain 89B-27 were both determined by IFC, there was no difference. The underestimation of the population size of 89B-27 based on rifampicin resistance was attributed to the inability of some cells to tolerate the stress from selective agents (e.g., rifampicin) present in selective media; some cells from soil samples are thought to be injured or to have altered cellular physiology due to environmental stresses. Similar phenomena have been reported in other systems $(26,43,48)$. Therefore, we were surprised to find nearly a perfect correlation in the population sizes detected by colony hybridization and the other two techniques, because the $1 / 3 \times \mathrm{KMB}^{+++}$rif agar and broth used in the dilution plating and the PCR-based dilution endpoint assay, respectively, contain rifampicin at $100 \mu \mathrm{g} / \mathrm{ml}$. The impact of ampicillin $(40 \mu \mathrm{g} / \mathrm{ml})$ and chloramphenicol $(13 \mu \mathrm{g} / \mathrm{ml})$ in the media was not considered as a factor in this study, but the recovery of other introduced fluorescent pseudomonads from the rhizosphere has not been reduced in the past by these antibiotics (D. M. Weller, unpublished data). Fluorescent pseudomonads have an intrinsic resistance to low levels of ampicillin and chloramphenicol, but rifampicin-resistant variants must be selected.

In the past, PGPR have been selected primarily by an empirical approach in which hundreds or thousands of strains are isolated and screened in vitro and under controlled conditions, and a few are selected for field testing. To date, little attention has been given to the genetic diversity within a group of PGPR that share a common biological control or growth-promoting trait (32). Molecular techniques now exist to identify and exploit this natural diversity in PGPR populations, and the techniques described in this report can be used to track multiple genotypes in rhizosphere studies. We currently are using all three of the approaches described to develop detailed descriptions of rhizosphere population dynamics of natural or introduced 2,4-DAPG-producing Pseudomonas spp. and to determine the competitiveness or specificity of different $p h l D^{+}$genotypes for a particular crop.

\section{ACKNOWLEDGMENTS}

This research was supported by grants 97-35107-4804 and 01-351071011 from the U.S. Department of Agriculture, National Research Initiative, Competitive Grants Program. B. B. Landa was the recipient of a postdoctoral fellowship from the Fulbright Commission and the Spanish Ministry of Science and Technology. We thank A. Brown, C. E. Sachs, and L. Wagoner for technical assistance; L. S. Thomashow and P. A. Okubara for helpful comments; and D. M. Mavrodi for the phlD sequences alignment.

\section{LITERATURE CITED}

1. Bakker, P. A. H. M., Lamers, J. G., Bakker, A. W., Marugg, J. D., Weisbeek, P. J., and Schippers, B. 1986. The role of siderophores in potato tuber yield increase by Pseudomonas putida in a short rotation of potato. Neth. J. Plant Pathol. 92:249-256.

2. Bangera, M. G., and Thomashow, L. S. 1999. Identification and characterization of a gene cluster for synthesis of the polyketide antibiotic 2,4diacetylphloroglucinol from Pseudomonas fluorescens Q2-87. J. Bacteriol. 181:3155-3163.

3. Bonsall, R. F., Weller, D. M., and Thomashow, L. S. 1997. Quantification of 2,4-diacetylphloroglucinol produced by fluorescent Pseudomonas spp. in vitro and in the rhizosphere of wheat. Appl. Environ. Microbiol. 63:951-955.

4. Cronin, D., Moënne-Loccoz, Y., Fenton, A., Dunne, C., Dowling, D. N., and O'Gara, F. 1997. Ecological interaction of a biocontrol Pseudomonas fluorescens strain producing 2,4-diacetylphloroglucinol with the soft rot potato pathogen Erwinia carotovora subsp. atroseptica. FEMS Microbiol. Ecol. 23:95-106.

5. Cronin, D., Moënne-Loccoz, Y., Fenton, A., Dunne, C., Dowling, D. N., and O'Gara, F. 1997. Role of 2,4-diacetylphloroglucinol in the interaction of the biocontrol pseudomonad strain F113 with the potato cyst nematode Globodera rostochiensis. Appl. Environ. Microbiol. 63:1357-1361

6. Dekkers, L. C, Phoelich, C. C., van der Fits, L., and Lugtenberg, B. J. J. 1998. A site-specific recombinase is required for competitive root colonization by Pseudomonas fluorescens WCS365. Proc. Natl. Acad. Sci. USA 95:7051-7056.

7. Delany, I., Sheehan, M. M., Fenton, A., Bardin, S., Aarons, S., and O'Gara, F. 2000. Regulation and production of the antifungal metabolite 2,4-diacetylphloroglucinol in Pseudomonas fluorescens F113: Genetic analysis of $p h l F$ as a transcriptional repressor. Microbiology 146:537546 .

8. Duffy, B. K., and Défago, G. 1997. Zinc improves biocontrol of Fusarium crown and root rot of tomato by Pseudomonas fluorescens and represses the production of pathogen metabolites inhibitory to bacterial antibiotic biosynthesis. Phytopathology 87:1250-1257.

9. Durisin, M. D., Ibrahim, A., and Griffiths, M. W. 1997. Detection of pathogenic Yersinia enterocolitica in milk and pork using a DIG-labeled probe targeted against the yst gene. Int. J. Food Microbiol. 37:103-112.

10. Fenton, A. M., Stephens, P. M., Crowley, J., O'Callaghan, M., and O'Gara, F. 1992. Exploitation of gene(s) involved in 2,4-diacetylphloroglucinol biosynthesis to confer a new biocontrol capability to a Pseudomonas strain. Appl. Environ. Microbiol. 58:3873-3878.

11. Gerhardt, P., Murray, R. G. E., Wood, W. A., and Krieg, N. R. 1994. Methods for general and molecular bacteriology. The American Society for Microbiology, Washington, D.C.

12. Harrison, L. A., Letendre, L., Kovacevich, P., Pierson, E., and Weller, D. M. 1993. Purification of an antibiotic effective against Gaeumannomyces graminis var. tritici produced by a biocontrol agent, Pseudomonas aureofaciens. Soil Biol. Biochem. 25:215-221.

13. Howell, C. R., and Stipanovic, R. D. 1979. Control of Rhizoctonia solani on cotton seedlings with Pseudomonas fluorescens and with an antibiotic produced by the bacterium. Phytopathology 69:480-482.

14. Keel, C., Schnider, U., Maurhofer, M., Voisard, C., Burger, D., Haas, D., and Défago, G. 1992. Suppression of root diseases by Pseudomonas fluorescens CHA0: Importance of the bacterial secondary metabolite 2,4diacetylphloroglucinol. Mol. Plant-Microbe Interact. 5:4-13.

15. Keel, C., Weller, D., Natsch, A., Défago, G., Cook, R. J., and Thomashow, L. S. 1996. Conservation of the 2,4-diacetylphloroglucinol biosynthesis locus among fluorescent Pseudomonas strains from diverse geographic locations. Appl. Environ. Microbiol. 62:552-563.

16. Kloepper, J. W., Lifschitz, R., and Schroth, M. N. 1988. Pseudomonas inoculants to benefit plant production. Pages 60-64 in: ISI Atlas of Science. Institute for Scientific Information, Philadelphia.

17. Kluepfel, D. A. 1993. The behavior and tracking of bacteria in the rhizosphere. Annu. Rev. Phytopathol. 31:441-472.

18. Mahaffee, W. F., Bauske, E. M., van Vuurde, J. W. L., van der Wolf, M., van den Brink, M., and Kloepper, J. W. 1997. Comparative analysis of antibiotic resistance, immunofluorescent colony staining, and a transgenic marker (bioluminescence) for monitoring the environmental fate of a rhizobacterium. Appl. Environ. Microbiol. 63:1617-1622.

19. Martin, J. K. 1975. Comparison of agar media for counts of viable soil bacteria. Soil Biol. Biochem. 7:401-402.

20. Mavrodi, O. V., McSpadden Gardener, B. B., Mavrodi, D. V., Bonsall, R. F., Weller, D. M., and Thomashow, L. S. 2001. Genetic diversity of phlD from 2,4-diacetylphloroglucinol-producing fluorescent Pseudomonas species. Phytopathology 91:35-43.

21. Mazzola, M., Cook, R. J., Thomashow, L. S., Weller, D. M., and Pierson, L. S., III. 1992. Contribution of phenazine antibiotic biosynthesis to the 
ecological competence of fluorescent pseudomonads in soil habitats. Appl. Environ. Microbiol. 58:2616-2624.

22. McSpadden Gardener, B. B., Mavrodi, D. V., Thomashow, L. S., and Weller, D. M. 2001. A rapid PCR-based assay characterizing rhizosphere populations of 2,4-DAPG-producing bacteria. Phytopathology 91:44-54.

23. McSpadden Gardener, B. B., Schroeder, K. L., Kalloger, S. E., Raaijmakers, J. M., Thomashow, L. S., and Weller, D. M. 2000. Genotypic and phenotypic diversity of phl-D-containing Pseudomonas isolated from the rhizosphere of wheat. Appl. Environ. Microbiol. 66:1939-1946.

24. Meghrous, J., Fliss, I., Bouksaim, M., and Lacroix, C. 1999. Digoxigeninlabeled probe for rapid identification of nisinogenic Lactococcus lactis strains. FEMS Microbiol. Lett. 171:43-48.

25. O'Sullivan, D. J., and O'Gara, F. 1992. Traits of fluorescent Pseudomonas spp. involved in suppression of plant root pathogens. Microbiol. Rev. 56:662-676.

26. Pedersen, J. C., and Leser, T. D. 1992. Survival of Enterobacter cloacae on leaves and in soil detected by immunofluorescence microscopy in comparison with selective plating. Microbiol. Releases 1:95-102.

27. Picard, C., Di Cello, F., Ventura, M., Fani, R., and Guckert, A. 2000. Frequency and biodiversity of 2,4-diacetylphloroglucinol-producing bacteria isolated from the maize rhizosphere at different stages of plant growth. Appl. Environ. Microbiol. 66:948-955.

28. Pierson, E. A., and Weller, D. M. 1994. Using rhizobacteria mixtures to improve the consistency and effectiveness of biological control of take-all of wheat. Phytopathology 84:940-947.

29. Raaijmakers, J. M., Bitter, W., Punte, H. L. M., Bakker, P. A. H. M., Weisbeek, P. J., and Schippers, B. 1994. Siderophore receptor PupA as a marker to monitor wild-type Pseudomonas putida WCS358 in natural environments. Appl. Environ. Microbiol. 60:1184-1190.

30. Raaijmakers, J. M., Bonsall, R. F., and Weller, D. M. 1999. Effect of population density of Pseudomonas fluorescens on production of 2,4-diacetylphloroglucinol in the rhizosphere of wheat. Phytopathology 89:470-475.

31. Raaijmakers, J. M., and Weller, D. M. 1998. Natural plant protection by 2,4-diacetyl-phloroglucinol-producing Pseudomonas spp. in take-all decline soils. Mol. Plant-Microbe Interact. 11:144-152.

32. Raaijmakers, J. M., and Weller, D. M. 2001. Exploiting genotypic diversity of 2,4-diacetylphloroglucinol-producing Pseudomonas spp.: Characterization of superior root-colonizing P. fluorescens strain Q8r1-96. Appl. Environ. Microbiol. 67:2545-2554.

33. Raaijmakers, J., Weller, D. M., and Thomashow, L. S. 1997. Frequency of antibiotic-producing Pseudomonas spp. in natural environments. Appl. Environ. Microbiol. 63:881-887.

34. Ramette, A., Moënne-Loccoz, Y., and Défago, G. 2001. Polymorphism of the polyketide synthase gene phlD in biocontrol fluorescent pseudomonads producing 2,4-diacetylphloroglucinol and comparison of PhlD with plant polyketide synthases. Mol. Plant-Microbe Interact. 14:639652 .
35. Sambrook, J., Fritsch, E. F., and Maniatis, T. 1989. Molecular Cloning: A Laboratory Manual. 2nd ed. Cold Spring Harbor Laboratory, Cold Spring Harbor, NY.

36. Schnider, U., Keel, C., Blumer, C., Troxler, J., Défago, G., and Haas, D. 1995. Amplification of the housekeeping sigma factor in Pseudomonas fluorescens $\mathrm{CHA} 0$ enhances antibiotic production and improves biocontrol abilities. J. Bacteriol. 177:5387-5392.

37. Schroeder, K. L., Raaijmakers, J. M., Kalloger, S. E., Mavrodi, D. V., Thomashow, L. S., Cook, R. J., and Weller, D. M. 1998. Distribution of 2,4diacetylphloroglucinol-producing Pseudomonas spp. with extended monoculture. (Abstr.) Phytopathology 88(suppl.):S80.

38. Shanahan, P., O'Sullivan, D. J., Simpson, P., Glennon, J. D., and O'Gara, F. 1992. Isolation of 2,4-diacetylphloroglucinol from a fluorescent pseudomonad and investigation of physiological parameters influencing production. Appl. Environ. Microbiol. 58:352-358.

39. Smith, K. P., and Goodman, R. M. 1999. Host variation for interactions with beneficial plant-associated microbes. Annu. Rev. Phytopathol. 37: 473-491.

40. Stutz, E., Defago, G., and Kern, H. 1986. Naturally occurring fluorescent pseudomonads involved in suppression of black root rot of tobacco. Phytopathology 76:181-185.

41. Thomashow, L. S., and Weller, D. M. 1995. Current concepts in the use of introduced bacteria for biological disease control: Mechanisms and antifungal metabolites. Pages 187-235 in: Plant-Microbe Interactions, Vol. 1. G. Stacey and N. Keen eds. Chapman and Hall, New York.

42. van Loon, L. C., Bakker, P. A. H. M., and Pieterse, C. M. J. 1998. Systemic resistance induced by rhizosphere bacteria. Annu. Rev. Phytopathol. 36:453-483.

43. van Overbeek, L. S., van Elsas, J. D., Trevors, J. T., and Starodub, M. E. 1990. Long-term survival of and plasmid stability in Pseudomonas fluorescens and Klebsiella species and appearance of nonculturable cells in agricultural drainage water. Microbiol. Ecol. 19:239-249.

44. Vincent, M. N., Harrison, L. A., Brackin, J. M., Kovacevich, P. A., Mukerii, P., Weller, D. M., and Pierson, E. A. 1991. Genetic analysis of the antifungal activity of a soilborne Pseudomonas aureofaciens strain. Appl. Environ. Microbiol. 57:2928-2934.

45. Weller, D. M. 1983. Colonization of wheat roots by a fluorescent pseudomonad suppressive to take-all. Phytopathology 73:1548-1553.

46. Weller, D. M., and Cook, R. J. 1983. Suppression of take-all of wheat by seed treatments with fluorescent pseudomonads. Phytopathology 73:463469.

47. Weller, D. M., and Thomashow, L. S. 1994. Current challenges in introducing beneficial microorganisms into the rhizosphere. Pages 1-18 in: Molecular Ecology of Rhizosphere Microorganisms. F. O'Gara, D. N. Dowling, and B. Boesten, eds. VCH, Weinheim, Germany.

48. Wilson, M., and Lindow, S. E. 1992. Relationship of total viable and culturable cells in epiphytic populations of Pseudomonas syringae. Appl. Environ. Microbiol. 58:3908-3913. 